\title{
The Compatriot Magazine "Jednota": A Mirror of Hundred-Year History of Slovak Immigrants in the USA
}

\author{
Michaela Bakay-Zahorska - Zdena Kralova
}

\section{DOI: 10.18355/XL.2015.08.03.66-75}

\begin{abstract}
It was mainly the Slovak-American press that had unified the Slovak immigrant community in the USA. It represented a relevant source of information about the Slovak community life as well as about the situation back home in Europe. Today, the preservation of Slovak cultural heritage in an extensive assimilation process of the American Slovaks in the USA is of high significance. The primary objective of the article is to summarize the data obtained by the study of one of the most influencial compatriot periodicals (Jednota - The Union) in the USA as it represents an important part of the Slovak cultural heritage.
\end{abstract}

Key words

Slovak immigration, USA, compatriot periodicals

Immigrant communities abroad represent a relevant part of the history of both home and host countries. Cultural heritage of immigrants reflects their life abroad as well as the situation back at home from their point of view. Cultural identity and language preservation of minorities living abroad are involved in charters and conventions of both national and international associations. All of them emphasize the importance of enhancing and supporting the activities of compatriots living abroad that keep them linked with their native country.

The UNESCO and the European Council have the responsibility to formulate strategies and policies to respect and protect the traditional knowledge, to safeguard the linguistic heritage and to support expression, creation and dissimilation in the greatest possible number of languages. More than 2.8 million people of Slovak origin are scattered all over the world of which two thirds live in the USA (Holeštiak, 2002). However, the Slovak Republic has joined these activities only after the fall of communism in 1989. The period before had represented a dark side of the flow of information about the Slovak immigration and their activities.

One of the primary goals of Slovak foreign policy today is to protect the linguistic, cultural and religious identity of Slovak immigrants and to assure the cooperation and communication between the Slovak Republic and the compatriot organizations abroad. Consequently, the Slovak government has committed to consecutive financial intervention to encourage compatriot publishers and literary work of fraternal societies to meet international agreements. As the manifestation of the Slovak culture preservation abroad is reflected mainly in literary and publishing work, theatrical and musical performance and folk art.

The framework of Slovak cultural identity is formed by three major elements - community, language and religion. To keep the Slovak cultural and national identity in the context of political and social situation both in Europe and in America was not easy. In early years of Slovak settlement in the USA, the Slovaks were just anonymous ethnic group within a large multi-ethnical environment. Since the Slovak national identity was not assured until the gain of independence from 1939 to 1945 and then later in 1993, religion played an important role in their self-identity. It represented an integral part of the Slovak everyday life and their struggle with tough reality. Christian traditions, holiday rituals and customs were kept in immigrant 
households where international marriages were not common due to the strong traditions and belief in returning home.

Nevertheless, Slovak culture in America has remained alive thanks to the devoted Slovak American descendents. The new living conditions and experience in a multinational America had brought significant change in social, cultural and political activities of Slovak immigrants. From the underestimated people they had developed to the nation aware of their national roots and linked together by their mutual needs and patriotism. This trend paved the path for organizing themselves both for protection and social support in a foreign country.

The cornerstone of the Slovak cultural heritage preservation is built on three essential pillars: parish churches, press and fraternal organizations (Stolarik, 2012). Mostly Slovak priests became their religious, social and national leaders. The first Slovak Catholic parish was founded in Hazleton, Pennsylvania in 1882 and the first Evangelical parish in Streator, Illinois, in 1884. During the last hundred years more than 240 Slovak Roman Catholic parishes in the United States established parochial schools to teach their children to read and write in Slovak (Paučo, 1965). The feeling of isolation and loneliness in the multicultural environment made the Slovak immigrants to establish the societies to assist the immigrants who fell ill or suffered from injuries at work.

Even in the early years of settlement in the northern part of the USA, the ethnic minorities learnt the principles of collectivism to deal with hard time they came across in a new world. In need of help in case of illness, fatal or serious injury, there were no social services provided by American employers. The beginnings of the first societies date back to the early seventeenth century and they had primarily social character. Scottish immigrants founded the first so-called self-help organizations that provided the essential services to their members. Later on other ethnic groups - Polish, Irish and Czech followed them (Stolarik, 1989).

Catholic religious traditions supported the Slovak intentions to gather for both their protection and loyalty. Soon, they formed their own institutions that helped them to survive in a capitalist economy. Their primary intention was to follow their social and national program, to offer their members help in need, to assist in parish churches and to establish the education centers and first press institutions. Many priests had left Austrian-Hungarian Empire to help build the intellectual life in Slovak communities in the USA. M. M. Stolárik (2012) reports about fifty beneficial societies that had been established by 1890 , twenty-five of them in Pennsylvania. Soon, more than 40 fraternal associations had been formed in the northeastern and mid-western part of the United States. By 1896 the scattered regional societies affiliated and transformed into full-fledge insurance companies.

The formation of The Slovak League of America in 1907 meant a breakthrough in the Slovak national and political activities. This institution managed to affiliate several fraternal-benefit associations under one strong institution. The League helped to declare the common state of Czechs and Slovaks on the federation basis by signing the Cleveland Agreement on 22 October 1915 followed by the Pittsburgh Agreement on 31 May 1918. It was the sign that Slovak Americans were strong enough to control their activities in not only the USA, but what is more important, also in Europe. The Slovak-fraternal organizations represented a radical change in thinking and allowed the Slovak communities to interfere into the political situation even in their homeland in Europe later on during the years of formation of the first independent Slovak Republic. Slovak Americans believed in the rights of Slovaks to self-determination even during the World War II. The discontent with the post-war situation resulted in the next wave of immigration into USA. 
Press was a significant unifying factor of Slovak immigrants abroad that helped to awaken their interest in national issues and encouraged them to speak up for their rights under many turbulent circumstances within a heterogeneous environment of a new home. The history of the first Slovak press activities in the USA dates back to 1885 . There were about 250 Slovak daily, weekly and monthly newspapers issued mostly in Northern America since then and their number had culminated over the years (Bartalská, 2008). They were formed as the reaction to the lack of relevant and unbiased international and local news for Slovak workers. It called for liberation movement back home in Austria-Hungary and expressed the Slovak American attitude to a postwar Czechoslovakia and independent Slovakia. Today, it is a great background material on Slovak American community life through centuries.

The respected historian on this subject, Konštantín Čulen (1942) listed about 246 titles. M. M. Stolárik (1987: 353) mentioned 220 releases and what is more, he provided a valuable demographic profile and a rate of press survival: "twenty-six of all Slovak-American newspapers published since 1885 have originated in Pittsburgh region and 41 percent in the Commonwealth of Pennsylvania. 50 percent of all Slovak-American newspapers lasted less than two years and 66 percent lasted less than seven years."

Currently, there are 13 Slovak compatriot periodicals published in the USA, almost all having both the printed and electronic version. Most Slovak-American press activities have always been highly dependent on fraternal societies as their editorial offices. The periodicals Jednota and The Slovak in America are two Slovak compatriot periodicals with the longest tradition of circulation currently published in the USA. The periodical Jednota was founded by Rev. S. Furdek in 1890. The magazine was accepted as the main periodical of the fraternal organization on the second convention of The First Slovak Catholic Union in Cleveland in 1891. Initially, Jednota had been published as a weekly, since the 1994 it has been released bi-weekly.

Today, Jednota represents the main body of the largest and the most significant Slovak American fraternal society with over 700 local lodges in the United States and Canada. Jednota has been the promoter and preserver of the Slovak culture in the northern part of the USA and Canada over more than a century. Its main intention was to satisfy the demand of Slovak immigrants for impartial information about Slovakia and about the activities of other branches of Slovak compatriot organizations in the USA and Canada.

The seventy-year history of The First Catholic Slovak Union and Jednota was reported in the publication of Jozef Paučo (1965). His extended publication covered the historical development of the society from their origins in 1890 to 1965 . However, there is still missing a publication that would provide a detailed form and content analysis of Slovak American newspapers and magazines and include current press activities of Slovak immigrants living in the North America. Therefore, we attempted to make an insight into the content of the magazine Jednota that might contribute to more complex overview of the past and present situation of Slovak American press activities as it represent a highly valuable source of information about the life of the Slovak communities in the USA.

We focused on the changes of language representation, structure of regulars and occurrence of topics in Jednota since 1893 to 2014. The total number of all released issues since 1893 is 5905 in 123 volumes. Figure 1 shows the dominance of language used in each decade of the circulation of the periodical. Changes in the dominant language of the periodical mirror the historical development of the Slovak settlement in the USA. 


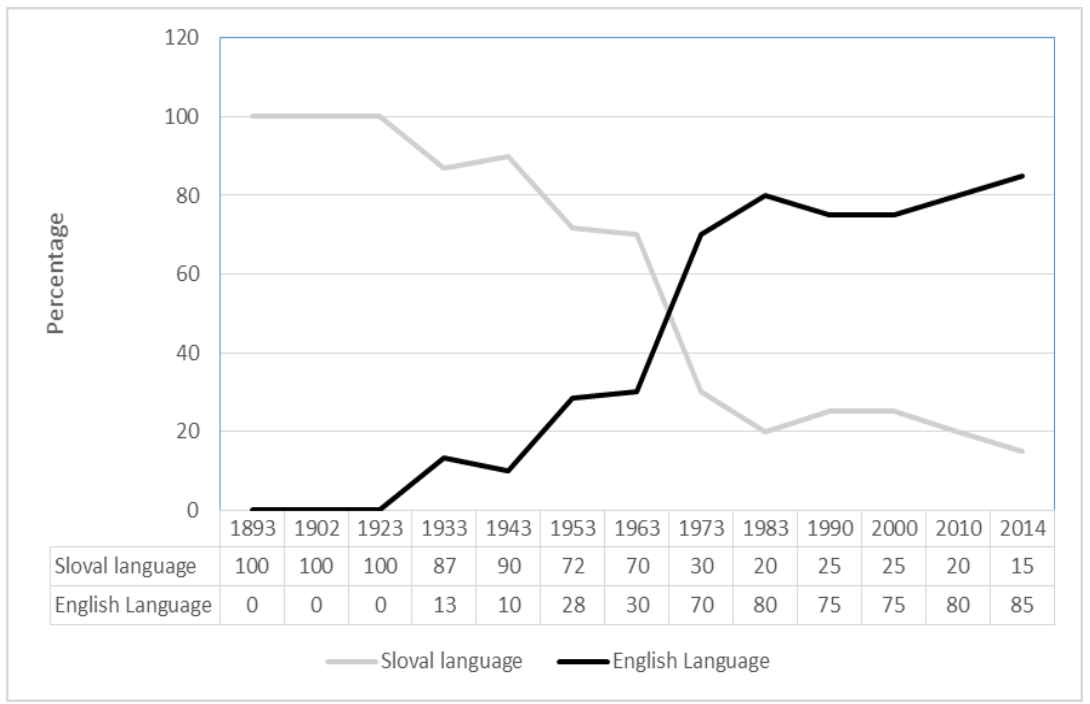

Figure 1 Language representation in Jednota

The prevalence of the Slovak language over English in the period from 1893 to $1923(100 \%)$ reflects the poor English language competence of the first wave of Slovak immigrants who did not have the intentions to settle down. Their desire was to save some money and return back home. What is more, the first generation of Slovaks in the USA did their best to preserve the Slovak language as a symbol of their national identity within the multicultural environment of the USA.

The years 1918-1933 represented the second wave of the Slovak immigration to the USA connected with the slight rise of English used mainly on the pages referring to sport listings. There is no significant difference in the language representation in next two decades. Slovak remained dominant (90\%) and the English texts included not only sport listings, but also official reports and district announcements. Significant change appeared between 1960s and 1970s (up to 70\% of English) which reflected the age of the next wave of the Slovak immigration to the USA. Many second-generation immigrants stopped passing on their mother tongue over their children. They were persuaded that mother tongue would not be useful for their children in their future in the USA (Hammer - Ripka, 1994). Later the Slovak language was limited to only a few regulars (Slovo Božie, Oznámenia spolkov and Slováci a ich život). In the end of the century, only the letters from Slovakia (Krátke správy zo Slovenska), district reports and the articles taken over from the Slovak newspapers were in Slovak.

The use of the mother tongue in the magazine issues copies the increasing level of assimilation of Slovak American community. The members of The First Slovak Catholic Union, who are the descendants of previous immigration waves to the USA, write most contributions now. They were involved in the American educational system and level of their mother tongue has been deteriorating. The mother tongue is actively used just in the older generation of Slovak Americans. However, the Slovak language remained preserved in vocabulary related to Slovak folk and religious traditions.

We monitored the changes of the columns in Jednota during the years 18932014. Their total number was 68 and the average annual number of columns within the whole period of was 14 . In 1890 s, Jednota started with 10 regular columns. The 
highest number of regulars appeared in 1990s probably due to dramatic political and social changes back in Slovakia. The issues of 2014 consisted of 12 regular columns. The most persistent regular was Sv. Evangelium that was later renamed to Slovo Božie but it kept the same discourse - purely religious and spiritual. It includes the topics such as Bible interpretations, reflections on God and Catholic traditions written by reverends or other church representatives of the Slovak community living in the USA. Dominant regulars have mostly informative character. They include the reports of the past community activities and community life which placed a great weight on solidarity and collaboration of all members of the Union as well as the whole Slovak American community.

Many regulars preserved their names and character; some regulars were added (Slovenský obzor), interrupted (Pod'akovania) or disappeared (Od Úradu Katolíckej slovenskej Jednoty) over the years of the publication. The regular Od našich dopisovatel'ov refers to the comments of the readers on common issues related to the Slovak American community life and Christianity. It contains articles, commentaries, interpretations and criticism of various aspects of their life in the USA. The regular has a great discourse value as it presents authentic feelings and attitudes of Slovak immigrants living abroad.

National and World News later differentiated as Zprávy z Uhorska, Zprávy z USA, Zo starej vlasti and Krátke správy zo Slovenska reflected the Slovak American interest in political, economic, social and national issues. Today, most of the articles in the regular Krátke správy zo Slovenska are not authentic but taken from the Slovak press agencies and selected with the focus on current political situation, preservation of Slovak cultural life and folk tradition with the pride of the current Slovak state sovereignty.

The magazine has not forgotten to take an interest in younger generation by publishing the regulars such as Pre tých našich mladších, later on renamed as Youth round up. The columns brought the fairy-tales, short stories and contests. Especially, the regular Proud of our Slovak youth, published since 1990s, placed a great weight on the educational achievements of young members of the community by presenting their profiles and informing the community about the scholarship grants. The regulars Slovak lessons and English-Slovak dictionary reflected the rise of English in the periodical since 1930s. They provided the members with the rules of Slovak grammatical structures and vocabulary to contribute to the Slovak language preservation in times of initial assimilation process.

We also coded the topics discussed in each issue of Jednota throughout the whole period of its circulation (Lynch - Peer, 2002). We found out the focus on topics with prevalently informative character, namely the official reports from the community (33\%) and national and world news (18\%). The magazine worked as the official organ of the society and the authors of the articles were mostly the official representatives of the society or the representatives of Catholic Church in the USA or Europe. To be in line with the official slogan of the society "For God and Nation", rather frequent were religious topics (28\%) - Bible interpretations, reflections on God, reports from the administration of church from the USA and Europe as well as the profiles of outstanding personalities. Specific emphasis was placed on tradition preservation and the Slovak literary contributions including poems, short stories or interpretations with the interest in Slovak culture and language mainly during the early circulation of the periodical. That time the assimilation process was not so evident.

The first issue of the magazine was devoted to the articles of religious and moral character. Its heading emphasized the idea to support the cultural identity of 
Slovaks in Europe: "Sbierky na literatúru na Slovensku sú najdôležitejší podnik pre národ slovenský” (Čulen, 1970: 51). In 1890s, most contributions dealt with the news from Austrian-Hungarian Empire and the information highly important for the Slovak American community - the decisions of the U.S. Congress related to labor market or political relations with other countries. The Slovak active participation in the socioeconomic issues was presented quite idealistic with reference to the Slovak participation in fight against exploitation at workforce. As the majority of Slovaks worked in coalmines and steel industry, the magazine commented on strikes that burst in the area. The active participation of Slovaks in various areas of life in America played a crucial role in their transformation from the oppressed people to autonomous nation. Almost the whole page of the periodical was devoted to the Bible interpretations. The essence of Slovak national feelings was reflected in identification of Slovaks with Christianity and Christian traditions.

The issues of 1900s corresponded to the character of the previous decade in terms of the persistence of religious and national news. The authors dealt with the Slovak position in the multi-ethnical environment. At the same time, the category "social issues" drew attention to the topics that reflected the socio-ethnical situation in Austrian-Hungarian Empire. Jednota's editorial board actively participated in agitation against the targeted magyarization in Austrian-Hungarian Empire and stressed the importance of the nation unity and fellowship. One of the most significant achievements of the society against Magyar oppression was to raise an objection against the transportation of Magyar flag to the USA without paying the toll. What is more, their active protests helped to stop the construction of the monument of Magyar agitator L'udovít Kossuth.

The most frequent themes of 1910 s remained the official reports from Jednota related to the membership and financial situation of the society and donations of the members. Jednota played an important role in dissemination of the information from homeland to their members. The editors stressed the importance of active members' participation in community matters. The feeling of the immigrants is reflected best in their literary contributions. The instructive poems drew attention to the importance of the fight for the Slovak language preservation.

The articles of 1920s mostly brought up the information from the official board of the society, news from church, news from homeland and the USA. The issues reflected the social status of Slovaks living in Czechoslovakia. The well-known Slovak writer, Martin Kukučín, contributed to Jednota by the article that called for the need to distribute books written in Slovak, as the ruling did not support the idea to raise the number of intellectuals in Slovakia. On the top of that, the great depression broke up in 1929 and the rate of unemployment in Europe as well as in America had risen. Slovaks could not afford to buy or print their own books in their homeland. Again, Jednota drew attention to that issue and agitated for the financial support. Except the articles that dealt with the political situation both in Europe and the USA, Jednota provided their members with the information about future job possibilities in various parts of the northern USA.

The official reports from Jednota in 1930s covered the most of the content of the analyzed issues and it involved just regular information about the activities of the branches of the society, the obituaries, and invitations to cultural events organized by the societies. It included the letters from community members who brought up the comments on the socio-economic situation of Slovaks living in the northern part of the USA. The First Slovak Catholic Union celebrated its 40th anniversary in 1931 and the reports from celebrations were published in the magazine. Jednota also reflected the celebrations of the 1,100 anniversary of the first built Slovak church in Slovakia.

In the years of a great economic crisis, the Union encouraged its members to fellowship as well as to political participation and unity. The magazine informed its 
members about the Slovak March in Washington and called for fund-raising. The Slovak March played an important role in Slovak integration into a large multiethnical community in the USA. The authors of the articles agitated the members to be more active in political and civil issues in terms of Slovak national identity preservation. At that time, Slovaks had been ideologically split over the issue of the position of Slovakia within Czechoslovakia. The turbulent years of the Slovak autonomy proclamation in 1938 were reflected in the magazine issues. The Slovak Americans were in favor of autonomous Slovakia and brought up the articles that rejected the dominance of pro-czechism. In terms of language, English was in rise. The editorial board lead by Philip A. Hrobák was aware of this fact and involved the columns with the focus on Slovak lexicology and grammar forms.

The 1940s depict the life of the Slovak American community at the time of World War II. The category News included the main reports from the war in Pacific and other parts of the world. The USA entered into the war in Pacific and Slovak Americans were actively involved in the war conflict as a part of American army. Although the Slovak Republic was considered to take part of the enemy, the Slovaks, hereby particularly Slovak Americans, played a heroic role as the members of American navy. The editorial board of Jednota put the great weight on personalities either from political, religious or cultural life. They released the profiles of Dr. Tiso, Andrej Hlinka, or for instance the profile of a Slovak banker Michal Bosák, who were described quite idealistically in terms of the fight for the Slovak sovereignty.

The themes of 1950s did not mark significant differences from the previous decade. The content of Jednota was strictly against totalitarianism in Slovakia. They brought up the information from the 33th Congress of the Slovak League of America that emphasized the idea of democratic way of life. The Slovak League of America had its own representative in Washington and he discussed Slovak political issues with U.S. representatives. The articles of Jednota commented on new immigration and nationality law that came to force in 1952 .

The 1960s were the years of the $70^{\text {th }}$ anniversary of The First Slovak Catholic Union. At the same time, the year 1963 was the year of the 1,100th anniversary of St Cyrilus and Methodius. The official reports from Jednota involved the articles that celebrated the Slovak traditions related to them. The news from church stressed the importance of priests in Slovakia as the church suffered from the communist oppression. The literary contributions written in Slovak consisted of the melodramatic and spiritual poems.

The issues in 1970s reported the further rise of religious and spiritual themes devoted to parishes administered by the Slovak Franciscans of Most Savior Custody. The regular column Slováci a ich život drew the attention to the personalities from Slovak religious life (e.g., Ján A. Ferienčík, Gustáv Maršall Petrovský, Anton Bielek and Jozef Hušek). Current political situation in Slovakia was described with the emphasis on the national rights implementation in terms of the Slovak relations with other states.

The early 1980s were characterized by the sharp rise of the English language. This trend reflects the fact that the members of Union were already the second, the third or the fourth generation of Slovak immigrants. Despite the start of the assimilation process and Slovakia being forcibly silenced by the communist dictatorship, the Slovak Americans had kept being aware of their national heritage because of their strong religious and national bonds. Other columns referred to the tribute to famous poets of Slovak origin such as Gorazd Zvonický whose numerous exile collections reflected his strong sense of Slovak patriotism.

Since 1994, the magazine was issued as bi-weekly. In terms of political issues, Jednota published the articles related to the transfer of regime in 
Czechoslovakia and political situation back home in 1990s. After long time of permanent advocacy of Slovak self-determination, the Slovak independence was achieved. The articles reflected the elections in Slovakia, reported the visit of the Slovak League of America delegation in Slovakia as well as the visit of the representatives of the Slovak World Congress. Jednota passionately followed the news from Slovak Catholic church and its members and it published their appeals for financial support that would help to establish the local Slovak Catholic churches. As the patron of Slovak language and culture preservation Jednota openly criticized the inter-ethnical relations in the Czechoslovak Federal Republic.

The category Education included the articles referred to the history of Academia Istropolitana or to Slovak schools established both in the USA and in Slovakia. The last decades of the twentieth century witnessed the major changes mainly in Eastern Europe. The efforts of Slovak Americans to resume the relations had strengthened at the next General Assembly of the Slovak World Congress, held in Cleveland in 1996. The delegation met with with the Slovak President and the Prime Minister. Finally, they managed to negotiate the holding of dual citizenship with Slovakia and the restorations of confiscated properties after 1948.

The issues of Jednota in 2000s were published with the dominance of official reports from Jednota and general news from Slovakia or the USA. The main headlines followed the efforts of the Slovak Republic to integrate geopolitically into the Central-European space. Jednota drew the Slovak tradition preservations and brought up the news about the personalities from Slovak cultural life. The magazine gave the information of building a Slovak Lutheran school in Missouri where Slovak language and culture were learnt. As far as language is concerned, Jednota brought up the profile of Slovak American university professor John Lihani from Kentucky who developed a revolutionary method of simplifying English for quicker and easier acquisition for everyone. Jednota presented the news about the new book release of Helen Cincebeaux featuring the full color photographs of her collections of Slovak folk art and wedding folk dresses. In the regular Krátke správy zo Slovenska the magazine started to publish the articles taken from Slovak media (via the press agency of the Slovak Republic - TASR).

Jednota in 2010s_is focused mainly on the news related to socio-economic situation in Slovakia. The cultural themes were related to art and literature. Jednota informed its members about newly opened exhibition of Andy Warhole's work displayed in Košice, Slovakia and the photogallery of the visit of E. A. Cernan in Kysuce Museum in Slovakia. The magazine kept releasing religious themes such as Reflections on Our Christianity. It contained many photographs documenting several cultural events of the Union members (for example, traditional Slovak Christmas). Most articles were taken from Slovak media and press agencies.

The liberation of Slovakia in 1989 has eased the ways of reunion of Slovak Americans with their relatives back in Slovakia and new types of media have influenced the character of their contacts. Despite the assimilation process, they keep in contact with their roots back home and exploit the opportunities to visit and explore Slovakia. A new generation of Slovak Americans living in the northern part of the USA has adopted bi-national identity that allowed them to scatter all-round the United States. The globalization and huge assimilation process resulted in their prevalent use of the English language, which allows them to find better job opportunities and social contacts. Even nowadays, in the years of democracy, we experience a new wave of immigration of mostly younger generation who migrate to the USA, Canada and Western Europe in seek for new job opportunities and experience. The exact number of those newcomers is hard to estimate due to the lack of central register of Slovak emigrants and a huge assimilation process. 
The Slovak American press represents an elaborated source of data related to the studies of compatriot affairs and even today, it plays a significant role in the transmission of the information about civic, political and cultural life of the community. Compatriot press together with the Slovak radio programs (Radio Slovakia USA launched in 2011) and other compatriot institutions, transmit the community heritage by publishing the news about the immigrant's native country or a community life in America.

Slovak American compatriot press has served as an important source of social, national and fraternal information for Slovak communities in the USA or Canada to maintain national awareness and education. The gradual change of living conditions in the community of Slovaks living in the USA has certainly changed their national identity awareness. The sincere interest in national, cultural and political issues in Slovakia in the community of Slovak Americans and an exclusive status in terms of inter-ethnicity of the USA is evident in Jednota. The magazine has reached out to readers with active interest in Slovak religious, political, cultural and social life in both Slovakia and the USA and the chronological thematic development of the articles reflects the socio-economic and cultural transformation of the Slovak community in the USA as well as in Europe.

The first decades of the magazine reflected the inner differentiation of the Slovak community over the language or national ideology. The fight against the communist oppression was mirrored in the publications where we found both critical and nationalistically oriented themes with the reference to the historical line of Christian tradition. The liberation of Slovakia from the communist oppression significantly changed the orientation of the magazine. The recent years of publication ceased the national agitation of the magazine and drew the attention to Slovak folk and cultural preservation.

Today, the magazine acts as a newsletter of The First Slovak Catholic Union. Despite the assimilation process of the Slovak community, mainly in terms of language, the full-color periodical documentation shows that the Slovak tradition has not faded out in the community of Americans with Slovak roots. The traditions such as Christmas, Easter or Cyrilus and Methodius Days are still celebrated in a Slovak traditional way. The traditional food such as saukraut soup, fish, peas, "bobalky", "pierohy", poppyseed or nut rolls are still enjoyed during the feasts. The magazine still provides the social security support for their members and publishes the reports on their insurance plan. The latest issues advertise various interesting heritage tours to Slovakia. It is admiring that despite high age, many Americans with Slovak roots are highly interested in participation in such events. Current issues present the Slovak community whose active participation in political and national issues outside the USA helped to establish the pride in liberated Slovakia and the magazine also reveals the pride of Slovak Americans in being an integrated part of the European community.

\section{References}

BARTALSKA, L. 2008. Kulturne dedicstvo Slovakov zijucich v zahranici a databaza informacii o tejto problematike. Bratislava: Úrad pre Slovakov zijucich v zahranici. ISBN 978-80-969-9211-9

CULEN, K. 1942. Dejiny Slovakov v Amerike. Bratislava: Slovenska Liga.

CULEN, K. 1970. Slovenske casopisy v Amerike. Cleveland, Prva Katolicka Slovenska Jednota.

HAMMER, L. B., RIPKA, I. 1994. Speech of American Slovaks. Bratislava: Veda. ISBN 802240151X 
HOLESTIAK, P. 2002. Slovenske media vo svete. Krajanske periodika v zahranici po obnoveni samostatnosti Slovenska. Čadca: Vzlet. ISBN 80-968759-3-0

LYNCH, S., PEER, L. 2002. Analyzing Newspaper Content [online]. http://www.readership.org/content/content_analysis/data/how-to.pdf.

PAUCO, J. 1965. 75 Rokov prvej Katolickej Slovenskej Jednoty. Cleveland, Prva slovenska katolicka jednota.

STOLARIK, M. M. 1987. The Slovak American Press. New York - London: Greenmont Press.

STOLARIK, M. M. 1989. Immigration and Urbanization: The Slovak Experience 1870-1918. New York: AMS Press. ISBN 040-419-4524

STOLARIK, M. M. 2012. Where is My Home - Slovak Immigration to North America 1870-2010. Bern: Peter Lang. ISBN 978-3-0343-1169-4

Words: 5298

Characters: 34339 (19,07 standard pages)

Mgr. Michaela Bakay-Záhorská, PhD.

Institute of Foreign Languages

University of Žilina

Žilina

Slovakia

michaela.bakayzahorska@ucj.uniza.sk

Assoc. Prof. Zdena Králová, PhD.

Dubnica Institute of Technology

Dubnica nad Váhom

Slovakia

zkralova@dti.sk 